\title{
Efisiensi Pemasaraan Telur Ayam Ras di Kecamatan Kanigoro Kabupaten Blitar
}

\author{
Jaisy Aghniarahim Putritamara $1^{1 *}$, Zaenal Fanani2 ${ }^{2}$ dan Hari Dwi Utami3 ${ }^{3}$ \\ ${ }^{1}$ Mahasiswa Program Pascasarjana Fakultas Peternakan, Universitas Brawijaya \\ ${ }^{2}$ Dosen Program Pascasarjana Fakultas Peternakan, Universitas Brawijaya \\ ${ }^{3}$ DosenProgram Pascasarjana Fakultas Peternakan, Universitas Brawijaya
}

\begin{abstract}
Abstrak
Tujuan penelitian ini adalah untuk menentukan pola saluran pemasaran dan efisiensi pemasaran telur ayam di kecamatan Kanigoro kabupaten Blitar. Tiga kelompok responden petani dipilih sebagai sampel convenience, grosir dan konsumen yang dipilih dengan metode purposive sampling. Pengambilan sampel dilakukan dengan selang snowball dengan kriteria bisnis lebih dari lima tahun. Pengumpulan dilakukan pada 12 Juni hingga 12 Juli 2014. Pengumpulan data primer melalui wawancara yang hasilnya diproses oleh analisis margin dan hasil kuesioner diolah melalui SmartPLS, sedangkan data sekunder terdiri dari informasi pemasaran dari petani dan pedagang. Metode pengumpulan data dilakukan dengan cara analisis data kuantitatif melalui perhitungan margin dan nilai share peternak dilakukan pendekatan kualitatif melalui analisis SCP, maka kualitatif analisis data dengan model persamaan struktural melalui SEM. Hasil penelitian menunjukkan bahwa lima pola saluran pemasaran yang terjadi di Kabupaten Blitar kecamatan Kanigoro untuk Grade AA dan A memiliki 4 pola saluran pemasaran, yaitu tipe 1 peternak - pedagang grosir - grosir pedagang kecil - konsumen, kemudian ketik 2 peternak - grosir pedagang - pedagang - konsumen, tipe 3 (a) peternak - pedagang grosir - konsumen, tipe 3 (b) peternak - pedagang grosir - minimarket dan jenis 4 peternak - hotel - konsumen. Share petani tertinggi dalam saluran pemasaran tipe 3 (a) sebagai peternak - pedagang grosir - konsumen dengan share peternak $91,08 \%$ dan mark-up sebesar Rp 1.600, -. Budaya, gaya hidup, harga pasar, jumlah pelanggan, kelompok sosial, persepsi berpengaruh positif terhadap efisiensi pemasaran.
\end{abstract}

Kata kunci: budaya, grosir, lingkungan, sampel convenience dan sosial

Abstract

The objective of research was to determine the pattern and efficiency of egg in Kanigoro district Blitar regency. Three groups of respondents farmers were selected convenience sampling, wholesalers and consumer were selected by purposive sampling method. Sampling was carried out trough snowball sampling technique with the business criteria of more than five years. Study was conducted at $12^{\text {th }}$ June until $12^{\text {th }}$ July 2014. Primary data including quantitative and qualitative data were collected by survey method using structural questionaire, the secondary data analyzed by SEM with smartPLS program. Results showed there are five the pattern of marketing channel. Marketing pattern 3 was found efficient in marketing that reffered by idr 1.600 and farmershare of $91,80 \%$. Cultural, lifestyle, market price, number of customers, social groups, perceptions positive effect on marketing efficiency.

Keywords: convenience sampling, cultural, environmental, social and wholesaler

\section{PENDAHULUAN}

Perekonomian yang baik dalam pembentukan pemenuhan bahan baku terutama bahan pangan berupa protein hewani, PDB (Produk Domestik Bruto) dan penyerapan tenaga kerja pada usaha di bidang peternakan. Pemanfaatan sumber daya alam pada bidang peternakan merupakan salah satu cara untuk menangani masalah kebutuhan pangan terutama masalah pemenuhan bahan baku pangan asal protein hewani, karena kondisi geografis di Indonesia

Alamat Korespondensi Penulis:

Jaisy Aghniarahim Putritamara

Email : Jaisyaghniarahimputritamara@gmail.com

Alamat : J. Siwalan RT:01/03, Klampok kecamatan Singosari, Malang. 65153

sangat mendukung peningkatan bidang agribisinis peternakan yang mampu memberikan pasokan protein hewani bagi masyarakat Indonesia yang selama ini masih dinilai rendah. Kecukupan kebutuhan pangan protein hewani merupakan salah satu langkah untuk, meningkatkan pertumbuhan perekonomian di Indonesia [1].

Jumlah produksi telur ayam ras yang fluktuatif terjadi pada setiap kabupaten di daerah Jawa Timur berdampak terhadap naik turunnya harga pada input produksi yang terus mengalami kenaikan sehingga harga telur ayam ras yang juga menjadi fluktuatif dan harga telur yang tidak stabil yang menjadikan salah satu faktor utama penyebab peternak untuk berhenti sejenak dalam menjalankan usaha budidaya telur ayam ras [2]. Harga ayam yang fluktuatif merupakan salah satu penyebab utama dalam pemasaran telur ayam ras di Jawa Timur karena dengan harga yang tidak stabil maka peternak akan kesulitan dalam menentukan harga pasar atau yang biasa disebut Farm Gate Price (FGP) sehingga menimbulkan persaingan yang tidak sehat antara 
produsen dengan pedagang perantara yang menimbulkan harga di konsumen akhir yang tidak efisien, sehingga terjadi keterkaitan antara penentuan harga di suatu daerah dengan daerah lain karena kemungkinan dengan banyaknya peternak yang berhenti sejenak dalam menjalankan usahanya artinya untuk pasokan telur di daerah tertentu terbatas akhirnya memasok kebutuhan telur ayam ras dari daerah lain [3].

Aktifitas pemasaran merupakan salah satu kegiatan yang paling penting, dimana pada kegiatan ini tujuannya adalah menyalurkan produk berupa telur ayam ras dari peternak sampai ke tangan konsumen akhir yang melibatkan bebrapa lembaga pemasaran untuk memudahkan produsen dalam menyalurkan telur[4]. Pemeran penting yang dapat mempengaruhi efisien atau tidaknya suatu pemasaran adalah pihak penentu harga yang menerima harga yang dapat diartikan bahwa orang tersebut adalah sebagai pelaku penting dalam pasar yang dapat mempengaruhi harga telur ayam ras, apabila seorang investor hanya bertindak sendiri maka tetap tidak bisa menentukan harga dari suatu sekuritas sehingga margin pemasaran memiliki nilai tinggi [5]. Pemasaran dapat dikatakan efisien apabila [6]. sistem tataniaga disebut efisien apabila memenuhi dua syarat yaitu mampu menyampaikan hasil-hasil dari petani ke konsumen dengan biaya yang murah dan mampu mengadakan pembagian yang adil dari keseluruhan harga yang dibayar konsumen akhir kepada semua pihak yang terlibat dalam kegiatan produksi dan jalur tataniaga tersebut.

Efisiensi pemasaran dipengaruhi oleh beberapa faktor diantaranya adalah hal-hal yang mendukung terjadinya pemasaran yang efisien yaitu struktur pasar, lembaga pemasaran yang ikut andil dalam proses pemasaran telur ayam ras dan transmisi harga telur ayam ras. Pengukuran efisiensi pemasaran telur ayam ras secara garis besar dapat dibedakan secara kualitatif dan kauntitatif. Pengukuran secara kualitatif dilakukan dengan cara mendefinisikan dan memaparkan antara pemasaran yang berkesinambungan dengan kesejahteraan konsumen dan kepuasan dengan menggunakan analisis melalui pendekatan teknik S-C-P, yaitu; market strcture, market conduct dan market performance [7]. Penelitian yang dilakukan difokuskan pada aspek pemasaran, yaitu dalam rangka menyampaikan produk telur ayam ras dari produsen hingga sampai ke tangan konsumen akhir maka akan diketahui apakah pemasaran tersebut telah dikatakan efisien atau tidak, dengan adanya efisiensi pemasaran maka biaya tetap dan tidak tetap selama budidya ayam petelur akan diketahui dari perbandingan kelayakan suatu pendapatan dan keuntungan yang diterima peternak dengan harga yang diterima konsumen akhir, sehingga konsumen akhir tidak merasa harga yang didapatkan terlalu mahal, selain itu peternak memiliki keuntungan yang sesuai dengan biaya yang dikelurkan saat proses pembudidayaan sampai proses pemasaran yang dilakukan.

\section{METODE PENELITIAN}

Penelitian dilaksanakan di Kecamatan Kanigoro Kabupaten Blitar pada bulan Juni sampai Juli 2014, pemilihan lokasi penelitian dilakukan dengan cara disengaja (purposive methode) dengan alasan bahwa kabupaten Blitar merupakan pemasok telur ayam ras paling banyak di propinsi Jawa Timur, apabila dihitung untuk propinsi Jawa Timur saja mampu memasok sekitar 70\%, sedangkan untuk kebutuhan telur nasional kabupaten Blitar mampu memasok kebutuhan telur sebanyak 30\% [8]. Di Kabupaten Blitar terdiri tiga kecamatan sebagai sentra peternakan ayam petelur yaitu kecamatan Srengat sebagai sentra paling banyak yaitu Tiga kecamatan pemasok telur terbanyak antara lain Kecamatan Srengat (23.847 kilogram), Kecamatan Kademangan (18.737 kilogram), dan Kecamatan Kanigoro (15.620 kilogram) [9].

\section{Metode Pengumpulan Data}

Pengambilan sampel penelitian pada peternak melalui convenience sampling, yaitu pengambilan sampel yang lokasinya telah dijumpai dengan populasi kepemilikian telur ayam ras kurang sama dengan 30.000 ekor ayam petelur, kemudian untuk pedagang dengan cara purposive yaitu kriteria pedagang yang menjalankan usahanya lebih dari 5 tahun [10]. Kecamatan Kanigoro merupakan kecamatan yang memiliki populasi ayam petelur yang banyak dari ketiga kecamatan dan mampu memasok kebutuhan telur ayam ras Indonesia. Metode penelitian yang digunakan dalam pelaksanaan penelitian ini adalah menggunakan metode diantaranya untuk metode survey dengan analisa data kuantitatif dalam hal ini adalah menghitung nilai margin pemasaran yang meliputi share peternak, share biaya, share keuntungan serta R/C Ratio yang dihitung berdasarkan masing-masing pola pemasaran yang terbentuk dari setiap usaha peternak yang dikelompokkan berdasarkan tempat pemasaran telur sesuai dengan grading yang dilakukan oleh peternak, setalah metode kuantittif tersebut telah memperoleh hasil,maka perlu dilakukan analisa data kualitatif melalui pendekatan analisa S-C-P untuk mengetahui efisien tidaknya pemasaran telur ayam ras di kecamatan Kanigoro kabupaten Blitar. Tahap berikutnya adalah analisa data kualitatif untuk mengetahui besarnya pengaruh variabel bebas dari lingkungan pemasaran yaitu faktor eksternal dan internal terhadap variabel terikat yaitu efisiensi pemasaran telur yam ras di kecamatan Kanigoro 
kabupaten Blitar. [11] Pedagang menengah dan kecil yang berada pada tingkat selanjutnya, ditentukan berdasarkan metode snowball sampling menurut informasi dari pedagang besar yang melakukan transaksi dengan mereka. Kondisi yang kerap terjadi yaitu seorang pedagang menengah melakukan transaksi dengan banyak pengecer. Apabila terjadi kondisi dimana pedagang menengah tidak dapat memberi informasi mengenai pengecer yang melakukan transaksi dengannya, maka digunakan tekhnik accidental sampling. Tekhnik ini digunakan dengan langsung menentukan pengecer yang ditemui di pasar saat penelitian berlangsung. Dengan berbagai metode sampling tersebut, diharapkan akan dapat menemukan sampel responden yang tepat dan dapat memberikan data dan informasi yang diperlukan dalam penelitian ini. Responden yang diperoleh yaitu para pelaku dalam lembaga-lembaga pemasaran yang benar-benar terlibat dalam saluran pemasaran telur ayam ras ke pasar. Selanjutnya, dari reponden yang kompeten tersebut, akan diperoleh informasi dan data primer yang aktual dan faktual yang diperlukan dalam penelitian.

\section{Variabel Penelitian}

Variabel independen pada pelaksanaan penelitian ini adalah efisiensi pemasaran telur ayam ras dimana pada pengamatan tersebut terdapat hasil dari biaya tetap dan biaya tidak tetap untuk mengetahui penerimaan setelah itu untuk mengetahui nilai marjin pemasaran, share peternak, keuntungan, biaya dan R/C Ratio yang diketahui melalui analisa data kuantitatif yang selanjutnya dianalisa dengan data analisa kualitatif dengan menggunakan analisa SC-P (dalam satu kali periode produksi), sedangkan untuk variabel dependen pada penelitian ini adalah peternak ayam petelur dan lembaga pemasaran telur ayam ras yang berperan sebagai distributor yang dianggap mampu mewakili total peternak ayam petelur keseluruhan yang ada di kecamatan Kanigoro kabupaten Blitar [12], kemudian untuk analisa kualitatif melalui smartPLS untuk mengetahui pengaruh positif dan negatif faktor eksternal dan internal terhadap efisiensi pemasaran. Variabel Independen pada indikator ini adalah lingkungan pemasaran yang terdiri dari dua indikator variabel bebas yaitu faktor eksternal dan internal lingkungan pemasaran kemudian untuk variabel dependen adalah efisiensi pemasaran.

\section{ANALISA DATA}

Analisa data kuantitatif menggunakan perhitungan margin pemasaran [13]. rumus margin pemasaran adalah sebagai berikut sebagai berikut: $\mathrm{Mp}=\mathrm{Pr}-\mathrm{Pf}$
Keterangan:

$$
\begin{array}{ll}
\mathrm{Mp} & =\text { Margin pemasaran }(\mathrm{Rp} / \mathrm{kg}) \\
\mathrm{Pr} & =\text { harga di tingkat konsumen }(\mathrm{Rp} / \mathrm{kg}) \\
\mathrm{Pf} & =\text { harga di tingkat produsen }(\mathrm{Rp} / \mathrm{kg})
\end{array}
$$

[14].farmer share merupakan bagian yang diterma oleh produsen atau peternak pada saat pemasaran dan bagian yang diterima produsen pada rumus berikut:

SPf $=\frac{\operatorname{Pf}}{\operatorname{Pr}} \times 100 \%$

Keterangan :

SPf = Share harga di tingkat peternak ayam petelur (\%).

$$
\begin{aligned}
& \mathrm{Pf}=\text { Harga di tingkat petani }(\mathrm{Rp} / \mathrm{Kg}) . \\
& \mathrm{Pr}=\text { Harga di tingkat konsumen }(\mathrm{Rp} / \mathrm{Kg}) .
\end{aligned}
$$$$
\text { Share biaya dan share keuntungan }
$$
pemasaran dapat dihitung dengan rumus:

$$
\mathrm{Sk}_{\mathrm{i}} \quad=\left(\mathrm{K}_{\mathrm{i}}\right) /(\mathrm{Pr}-\mathrm{Pf}) \times 100 \%
$$$$
\mathrm{Sb}_{\mathrm{i}} \quad=\left(\mathrm{B}_{\mathrm{i}}\right) /(\mathrm{Pr}-\mathrm{pf}) \times 100 \%
$$

Keterangan :

$\mathrm{Sk}_{\mathrm{i}}=$ Share keuntungan lembaga pemasaran ke- $\mathrm{i}$, $\mathrm{Sb}_{\mathrm{i}}=$ Share biaya pemasaran ke-i.

Menghitung nilai efisiensi telur ayam ras [15].sebagai berikut :

EPS = (Biaya pemasaran / nilai produk yang dipasarkan) x 100\%,

Jika :

Eps $>1$ berarti tidak efisien

Eps $<1$ berarti efisien

Analisis data kualitatif untuk mengetahui efisiensi pemasaran di kecamatan Kanigoro kabupaten Blitar menggunakan Structur-Conduct-Performance (SC-P) dan menggunakan analisa data kualitatif Structural Equation Modeling (SEM) menggunakan program SmartPLS 2.0. SEM digunakan dengan alasan variabel-variabel yang digunakan adalah variabel laten yang diukur dengan berbagai macam indikator. Sehingga memungkinkan peneliti untuk menentukan apakah variabel tertentu memberikan pengaruh yang positif, seberapa besar pengaruhnya dan seberapa baik indikator variabel tersebut bekerja. Variabel laten adalah variabel yang tidak bisa diukur secara langsung dan memerlukan beberapa indikator sebagai proksi. Cara pengukuran konstruk tersebut adalah dengan skala Likert [16].

\section{HASIL DAN PEMBAHASAN}

\section{Sistem Pemasaran Telur Ayam Ras}

Pemasaran telur ayam ras di kecamatan Kanigoro merupakan pemasaran dengan jenis pasar oligopsoni, dimana penentuan harga yang terjadi di pasar dipengaruhi oleh pembeli selain itu produk merupakan bahan mentah yang mudah rusak (perishable) sehingga harus dijual kepada pedagang 
dan bukan kepada konsumen akhir pada saat pemasaran telur ayam ras berlangsung, artinya dikatakan pasar persaingan sempurna dimana barang bebas keluar masuk pasar dan banyak penjual dan pembeli yang ikut serta dalam pemasaran, selain itu penjual dan pembeli tidak bisa mempengaruhi harga karena harga dipegaruhi oleh penawaran dan permintaan [17].

Hasil survei yang dilakukan bahwa pemasaran telur ayam ras dilakukan oleh lembaga pemasaran yang ikut andil dalam memasarkan telur ayam ras, hingga telur sampai ke tangan konsumen dengan baik dan harapannya harga yang diterima konsumen masih dengan harga normal agar konsumen masih bisa mengkonsumsi telur ayam ras untuk memenuhi kebutuhan akan gizi telur. Telur ayam ras diproduksi oleh peternak ayam petelur yang ada di kecamatan Kanigoro kemudian dijual kepada lembaga pemasaran yang terdekat dengan produsen yaitu pengepul dengan jumlah telur ayam ras yang diambil oleh pengepul sebanyak $22.000 \mathrm{~kg}$, sistem pembelian yang berlaku biasanya pedagang mengambil telur ayam ras di peternak dilakukan satu sampai tiga hari sekali apabila permintaan akan telur meningkat karena harga murah. Harga telur yang dierikan oleh produsen ke pengepul adalah $\mathrm{Rp}$ 14.300,-- Harga tersebut termasuk harga selama budidaya ayam petelur yang dihitung setiap bulannya saat telur produksi yang meliputi pengkalkulasian dari biaya tetap dan biaya tidak tetap yang diketahui dari perhitungan penerimaan dan keuntungan, untuk FGP (Farm Gate Price) yaitu dengan harga $\mathrm{Rp} 14.300,-/ \mathrm{kg}$ harga tersebut lebih dari harga BEP yaitu sebesar Rp 12.888,$/ \mathrm{kg}$. Penentuan harga telur ayam ditentukan berdasarkan beberapa pertimbangan diantaranya adalah melaui mekanisme kebijakan untuk harga dasar telur ayam ras pada saat itu, yaitu ketika panen telur maka pemerintah berperan dalam menentukan harga dasar, kemudia menentukan harga telur yang berlaku saat itu (ekuilibrium), mekanisme pada harga telur tertinggi dengan tujuan untuk melindungi konsumen dari harga telur ayam ras yang mahal dan mekanisme kebijakan harga perangsang dengan tujuan agar peternak mau memproduksi telur ayam ras dengan jumlah yang lebih banyak [18]. Pedagang grosir juga memiliki pengkalkulasian yang hampir sama dengan pengepul yang juga mengambil barang ke pengepul sehingga memerlukan biaya pemasaran dan dapat diketahui bahwa untuk grosir menawarkan harga telur ayam ras sebesar $\mathrm{Rp} 15.900,-/ \mathrm{kg}$ sedangkan grosir membeli telur ayam ras dari pengepul dengan harga $\mathrm{Rp} 15.000,-/ \mathrm{kg}$. Telur ayam ras yang dijual oleh grosir adalah $10.000 \mathrm{~kg}$, sedangkan pengecer menjual telur dengan harga Rp 16.700,-.

Peternak ayam petelur tidak hanya memasarkan telur ayam ras ke lembaga pemasaran seperti halnya pedagang saja akan tetapi juga menjual ke segmen pasar seperti minimarket dan tempat komersil lain seperti yayasan sosial dan rumah sakit yang ada di Blitar dan luar kota. Peternak menjual telur ayam ras sesuai dengan jumlah permintaan konsumen dan menjual berdasarkan grading yang dilakukan sebelum telur dipasarkan. Grade AA dan A dijual ke lembaga pemasaran seperti pedagang dan minimarket dengan harga yang berbeda. Grade B khusus dijual ke tempat komersil karena telur langsung dikonsumsi dan permintaan juga stabil dengan jumlah yang sama.

\section{Nilai Margin Lembaga Pemasaran}

Margin merupakan perbedaan harga antara produsen dengan harga yang diterima konsumen akhir, semakin tinggi margin maka biaya yang dikeluarkan saat pemasaran semakin banyak [19]. Berikut penjelasan nilai margin pemasaran yang diperoleh oleh lembaga pemasaran berdasarkan tipe saluran pemasaran yang terbentuk, yaitu dari tipe 1 sebagai rantai panjang dengan banyak lembaga yang ikut memasarkan hingga tipe 3 yang hanya menggunakan jasa pengepul sebagai penyalur telur ayam ras. Saluran pemasaran tipe satu merupakan saluran pemasaran yang banyak menggunakan lembaga pemasaran didalamnya yang ikut berperan dalam memasarkan telur ayam ras hingga ke konsumen akhir, sehingga banyak lembaga pemasaran mulai dari peternak, pedagang pengepul, pedagang grosir dan pedagang eceran yang menjalankan fungsi kegiatan pemasaran dari fungsi pertukaran, fungsi fisik dan fungsi fasilitas sehingga banyak mengeluarkan biaya, akan tetapi dengan saluran pendek yaitu tipe tiga biaya juga masih bisa banyak karena kemungkinan dengan saluran pendek tidak adanya efsiensi biaya sehingga banyak biaya yang dikeluarkan, misalnya adalah terlalu banyaknya biaya transportasi yang dikeluarkan akan tetapi penjualan telur ayam ras tidak memenuhi target jual di pasar sehingga telur tidak laku dijual karena permintaan pasar sedangmenurun. Hasil perbandingan dari biaya pemasaran dengan nilai produk pada saluran pemasaran tipe 1 tergolong efisien dimana semua lembaga pemasaran dari pedagang pengepul, grosir dan eceran bahwa pemasaran telur ayam ras efisien karena nilai EPS $<1$.

Pada saluran tipe dua peternak di kecamatan Kanigoro didatangi oleh pengepul dari daerah Blitar seperti dari kecamatan Kanigoro sendiri akan tetapi dengan desa yan berbeda seperti desa Kuningan, desa Jatinom dan desa Gogodeso yang pengepulnya datang untuk mengambil telur dengan harga $\mathrm{Rp} 14.300$,- yang kemudian dijual langsung ke pedagang grosir, grosir ini berada masih di wilayah kabupaten Blitar yang ada di kecamatan Kanigoro, bahkan ada yang diluar kecamatan yang menjadi grosir seperti kecamatan 
Garum dan Talun, bahkan di daerah Tulungagung yaitu kecamatan Rejotangan, masih dengan harga jual pedagang grosir yaitu dengan harga jual Rp 15.900,-Harga tersebut dipatok oleh pedagang grosir berdasarkan biaya yang dikeluarkan saat proses pemasaran berlangsung, dan dengan harga tersebut keuntungan masih tetap diperoleh oleh pedagang grosir. Hasil perbandingan dari biaya pemasaran dengan nilai produk pada saluran pemasaran tipe 2 tergolong efisien dimana semua lembaga pemasaran dari pedagang pengepul dan grosir bahwa pemasaran telur ayam ras efisien karena nilai EPS $<1$.

Tabel 1. Nilai Margin Saluran Pemasaran Tipe 1

\begin{tabular}{|c|c|c|c|c|c|c|c|c|}
\hline Nakreting Channels Type & Lembaga Pemasaran & $\begin{array}{l}\text { Harga Telur per kg } \\
\text { (Ro / kg) }\end{array}$ & $\begin{array}{l}\text { Nai largin } \\
\text { (Rp) }\end{array}$ & $\begin{array}{l}\text { \% Margin } \\
(\%)\end{array}$ & $\begin{array}{c}\text { Fammer Sarre } \\
(\%)\end{array}$ & $\begin{array}{l}\text { Share Keuntungan } \\
(\%)\end{array}$ & $\begin{array}{l}\text { Share Biaya } \\
(\%)\end{array}$ & RiC Ratio \\
\hline & Produsen / Peternak & & & & $855.63 \%$ & $\begin{array}{ll}61,42 \\
\end{array}$ & 38.53 & 1.59 \\
\hline & Biaya Produksi & 12888 & & & & & & \\
\hline & Keuntungan & 1,474 & & & & & & \\
\hline & Harga vual & 14,300 & & & & & & \\
\hline & Pengepul & & 700 & 29,17 & & 60,57 & 39,43 & 1,54 \\
\hline & Harga Beli & 14,300 & & & & & & \\
\hline & Biaya Pemasaran & 276 & & & & & & \\
\hline & Keunungaan & 424 & & & & & & \\
\hline & Harga vual & 15,000 & & & & & & \\
\hline \multirow[t]{11}{*}{1} & Pedagang Grosir & & 900 & 37,5 & & 56,33 & 43,67 & 1,29 \\
\hline & Harga Beli & 15,000 & & & & & & \\
\hline & Biaya Pemasaran & 393 & & & & & & \\
\hline & Keuntungan & 507 & & & & & & \\
\hline & Harga ulual & 15,900 & & & & & & \\
\hline & Retaller & & 800 & 33,33 & & 51,88 & 48,13 & 1,08 \\
\hline & Harga Beli & 15,900 & & & & & & \\
\hline & Biaya Pemasaran & 395 & & & & & & \\
\hline & Keuntungan & 415 & & & & & & \\
\hline & Harga Jual & 16,700 & & & & & & \\
\hline & Total Margin & & 2,400 & 100 & & & & \\
\hline
\end{tabular}

(Data Primer (diolah), Oktober 2014)

Tabel 2. Nilai Margin Saluran Pemasaran Tipe 2

\begin{tabular}{|c|c|c|c|c|c|c|c|c|}
\hline \multirow{2}{*}{ Marketing Channels Type } & \multirow{2}{*}{ Lembaga Pemasaran } & \multicolumn{2}{|c|}{ Harga Telur perkg Nilai Margin } & \multirow{2}{*}{$\begin{array}{c}\text { \%Margin } \\
(\%) \\
\end{array}$} & \multirow{2}{*}{$\begin{array}{c}\text { Share Hargag Peternak } \\
\left(y_{0}\right) \\
\end{array}$} & \multirow{2}{*}{$\begin{array}{c}\text { Share Keuntungan } \\
(\%) \\
\end{array}$} & \multirow{2}{*}{$\begin{array}{c}\text { Share Biaya } \\
(\%)\end{array}$} & \multirow{2}{*}{ R/C Ratio } \\
\hline & & $(\mathrm{Rp} / \mathrm{kg})$ & $(\mathbb{R P})$ & & & & & \\
\hline \multirow{14}{*}{2} & Produsen/Peternak & & & & 87,73 & 73,70 & 26,30 & 2,80 \\
\hline & Biaya Produksi & 12,888 & & & & & & \\
\hline & Keuntungan & 1,474 & & & & & & \\
\hline & Harga Jual & 14,300 & & & & & & \\
\hline & Pengepul & & 700 & & 35 & 60,57 & 39,43 & 1,54 \\
\hline & Harga Beli & 14,300 & & & & & & \\
\hline & Biayy Pemasaran & 276 & & & & & & \\
\hline & Keuntungan & 424 & & & & & & \\
\hline & Harga uual & 15,000 & & & & & & \\
\hline & Peddgang Grosit & & 1,200 & & 65 & 67,25 & 32,75 & 2,05 \\
\hline & Harga Beli & 15,000 & & & & & & \\
\hline & Biaya Pemasaran & 393 & & & & & & \\
\hline & Keuntungan & 807 & & & & & & \\
\hline & Harga Jual & 16,200 & & & & & & \\
\hline & Total Margin & & 1,900 & 100 & & & & \\
\hline
\end{tabular}

(Data Primer (diolah), Oktober 2014)

Saluran pemasaran tipe tiga melibatkan dua lembaga pemasaran dalam menjalankan kegiatan pemasaran yaitu antara peternak dan pedagang pengepul serta ada beberapa antara peternak dengan pihak minimarket. Saluran pemasaran tipe tiga diharapkan mampu meminimalisir pengeluaran biaya saat pemasaran dan memperkecil nilai margin sehingga ratio keuntungan dan biaya semakin tinggi dan lebih dari nilai titik impas serta farm share lebih dari $40 \%$. 30 orang responden yang dijadikan sampel untuk peternak hanya 4 orang saja yang mejalankan saluran pemasaran tipe tiga yang mendistribusikan melalui minimarket selebihnya peternak menjual ke padagang pengepul kemudian baru diterima oleh konsumen akhir. 4 Peternak tersebut sudah dikateorikan peternak yang menjalankan usahanya lebih dari 10 tahun dalam menjalankan usahanya, sehingga minimarket menumbuhkan kredibiltasnya kepada peternak tersebut karena mengetahui pangsa pasar dan hasil yang diproduksi bagus dan kualitas telur terjamin. Pedagang pengepul mengambil telur ayam ras dari peternak dengan jumlah 22.000 kg, , biaya pembelian telur ayam ras terdiri dari biaya pengiriman, sehingga dengan secara langsung harga telur ayam ras yang dijual ke minimarket lebih mahal, selain itu proses pengemasan telur dilakukan untuk menjaga kualitas telur agar tetap higine sehingga harga jual juga lebih mahal dibandingkan dengan konsumen akhir yang membeli ke retail di pasar.

Tabel 3. Nilai Margin Saluran Pemasaran Tipe 3 (a)

\begin{tabular}{|c|c|c|c|c|c|c|c|c|}
\hline \multicolumn{2}{|c|}{ 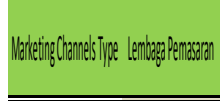 } & 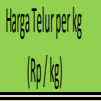 & 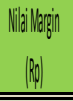 & 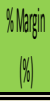 & 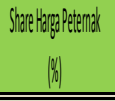 & $\begin{array}{l}\text { Share Keuntungan } \\
\qquad|y| x \mid\end{array}$ & $\begin{array}{c}\text { Shacbiald } \\
|y| x \mid \\
\end{array}$ & R/CRatio \\
\hline \multirow{9}{*}{3} & Produsen/Preternak & & & & $9,1,0$ & 80,390 & $11, \sqrt{5}$ & $7,5]$ \\
\hline & Biap Produsi & 11,280 & & & & & & \\
\hline & Keuthungal & 1,174 & & & & & & \\
\hline & Hageduld & 1,430 & & & & & & \\
\hline & Pengepdul & & 1,000 & $\mathbb{1 0}$ & & 82,75 & 17,6 & 400 \\
\hline & Hagebeli & $1 ., 300$ & & & & & & \\
\hline & Biappenzasen & 276 & & & & & & \\
\hline & Keutungen & 1,324 & & & & & & \\
\hline & Hapedollal & 15,900 & & & & & & \\
\hline & Iotal Maginn & & 1,000 & 100 & & & & \\
\hline
\end{tabular}

(Data Primer (diolah), Oktober 2014)

Pihak minimarket mengambil telur dengan jumlah rata-rata $15.000 \mathrm{~kg}$ dalam setiap bulannya. Alasan pihak minimarket langsung membeli telur dari produsen karena produsen yang melakukan grading dan harga jual lebih murah dari pada harus membeli ke pedagang pengepul, sebab minimarket juga mengeluarkan biaya dari kegiatan pemasaran seperti melakukan pengemasan, karena minimarket menjual telur ayam ras dalam keadaan bersih dan dicuci terlebih dahulu kemudia di press menggunakan sterofoam yag diberi palstik kemudian dimasukkan ke dalam lemari pendingin yang ada di minimarket, tentu harga jual di mainimarket lebih mahal karena pengolahannya atau pengemasannya lebih higienis. Grade yang dijual ke minimarket adalah grade AA dan A.

Saluran pemasaran tipe tiga (b) bahwa melalui pemasaran dari pihak minimarket farm share yang diterima lebih kecil dari farm share saluran pemasaran tipe satu, dua dan tiga (a) yaitu $84,12 \%$, 
sehingga dalam angka tersebut peternak mayoritas lebih memilih untuk memasarkan ke pengepul karena keuntungan yang didapatkan lebih banyak, dari 30 peternak yang menyalurkan telur ke pihak minimarket hanya 4 orang peternak saja, akan tetapi pemasaran tipe tiga (b) masih tergolong pemasaran yang efsien karena farm share masih lebih dari $40 \%$, begitu pula dengan share biaya yang dikeluarkan, hasilnya lebih besar dibandingkan tipe saluran pemasaran satu, dua dan tiga (A) secara berurutan dari peternak dan pihak minimarket adalah 45,41\% dan 39,07\%, makna dari nilai tersebut adalah bahwa setiap biaya yang dikeluarkan untuk produksi per bulan dalam nilai satuan kilogram dengan harga $\mathrm{Rp} 1,-$, peternak memberikan kontribusi biaya untuk peternak sebesar Rp 45,41,- sedangkan untuk pihak minimarket sebesar Rp 39,07 karena pihak minimarket biayanya besar pada pengemasan, karena minimarket menjual dalam bentuk telur bersih yang dikemas dalam streofoam dan dikemas dalam lemari pendingin. Keuntungan yang diterima peternak dan pihak minimarket adalah dengan prosentase sebesar 54,59\% dan 60,93\%, makna dari besarnya nilai tersebut adalah bahwa setiap harga yang dibayar oleh konsumen akhir sebesar Rp 1,- artinya peternak dan pengepul menerima keuntungan sebesar Rp 54,59,- dan Rp 60,93,- per kilogram telur. Hasil R/C Ratio menunjukkan bahwa saluran pemasaran tipe tiga (b) masih dikatakan efisien dengan alasan bahwa nilai $\mathrm{R} / \mathrm{C}$ Ratio peternak dan minimarket yaitu 1,20 dan 1,56, artinya nilai tersebut masih diatas nilai titik impas yang memiliki nilai 1 . Hasil perbandingan dari biaya pemasaran dengan nilai produk pada saluran pemasaran tipe 3 (A) dan 3 (B) tergolong efisien dimana semua lembaga pemasaran dari pedagang pengepul dan minimarket bahwa pemasaran telur ayam ras efisien karena nilai EPS $<1$.

Tabel 4. Nilai Margin Saluran Pemasaran Tipe 3 (b)

\begin{tabular}{|c|c|c|c|c|c|c|c|c|c|}
\hline \multicolumn{2}{|c|}{ Narketing Ghannes Tipe Lembaga Pemasaran } & 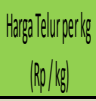 & $\begin{array}{l}\text { Distibusi } \\
|\mathbb{R} p|\end{array}$ & 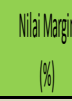 & gin $5 h$ & $\begin{array}{l}\text { Hage Petermak } \\
(y)\end{array}$ & are Kentung: & $\begin{array}{l}\text { Share biape } \\
(y) \mid\end{array}$ & R/CRatio \\
\hline \multirow{9}{*}{3} & Produsen/Peternak & & & & & 84. & 54 & 45 & 1212 \\
\hline & Biale Prouksi & 12888 & & & & & & & \\
\hline & Kentunnagan & $1,4,47$ & & & & & & & \\
\hline & Hargalual & 14,30 & & & & & & & \\
\hline & Minimarket & & 2,00 & & 100 & & 0 & & 907 \\
\hline & Hargbeli & 14,30 & & & & & & & \\
\hline & Biaplaemassan & 1,155 & & & & & & & \\
\hline & Kentungan & 1,645 & & & & & & & \\
\hline & Hargelual & 17,000 & & & & & & & \\
\hline & Tota| Magrin & & 2,700 & 100 & & & & & \\
\hline
\end{tabular}

(Data Primer (diolah), Oktober 2014)
Saluran pemasaran tipe 4 merupakan saluran pemasaran yang melibatkan peternak dan lembaga pemasaran dari pihak perhotelan di dalam pelaksanaan pemasaran telur ayam ras di kecamatan Kanigoro. Lembaga pemasaran tersebut melakukan serangkaian kegiatan pemasaran sesuai dengan tujuan awal yaitu menyalurkan telur ayam ras hingga konsumen akhir dalam bentuk olahan makanan yang disediakan di hotel, kemudian mendapatkan keuntungan dari hasil pemasaran tersebut. Saluran pemasaran tipe 4 mayoritas semua peternak yang sudah dilakukan survei menjalankan saluran pemasaran tipe 4 yang konsumen akhirnya membeli telur ayam ras dalam jumlah grosir yaitu kurang lebih $9.000 \mathrm{~kg}$

Tabel 5. Nilai Margin Saluran Pemasaran Tipe 4

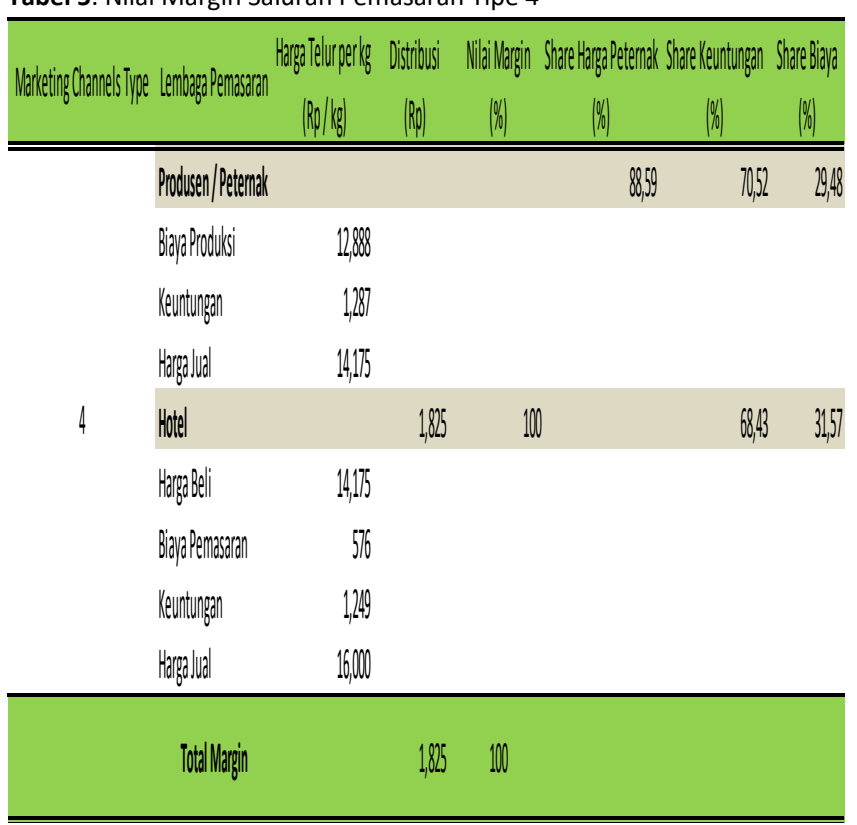

(Data Primer (diolah), Oktober 2014)

Berdasarkan hasil perhitungan nilai margin didapatkan hasil bahwa untuk lembaga pemasaran berupa hotel memiliki nilai share peternak sebesar 88,59 sedangkan untuk keuntungan pemasaran dikatakan efisien apabila nilainya mendekati $100 \%$ dan untuk biaya pemasaran harus kurang dari 50\% agar lembaga pemasaran mendapatkan keuntungan dari kegiatan pemasaran sehingga pemasaran dikatakan efisien

\section{Efisiensi Saluran Pemasaran melalui Pendekatan} Structure-Conduct-Performance (S-C-P) dan (P-C-S)

Secara umum antara S-C-P dengan P-C-S pengamatannya sama akan tetapi S-C-P ketersediaan produk setelah permintaan dan penawaran akan telur ayam ras ada, akan tetapi apabila P-C-S ketersediaan produk ada terlebih dahulu setelah itu muncul penawaran dan permintaan [20]. seperti halnya yang terjadi untuk P-C-S adalah adanya telur grade jumbo yang hanya memiliki pangsa pasar di satu wilayah dan 
hanya wilayah tertentu yang memasarkan ke tempat yang bersifat luxury seperti kapal pesiar, apabila daerah lain menjual grade jumbo maka akan dibeli oleh wilayah $A$ untuk dijual, karena wilayah lain hanya dapat menjual grade AA dan A serta B. Keuntungan yang diperoleh sama dengan produk yang belum tersedia akan tetapi penawaran dan permintaan ada.

\section{Struktur Pasar}

\section{* Jumlah Pedagang}

Hasil survei yang dilakukan di kecamatan Kanigoro kabupaten Blitar bahwa pedagang yang ikut serta dalam menjalankan kegiatan pemasaran telur ayam ras adalah 35 orang yaitu lembaga pemasaran yang terdiri dari pedagang pengepul, pedagang grosir dan pedagang kecil, yang masing-masing melaksanakan fungsi pemasaran sesuai dengan tujuannya yaitu sama-sama mendapatkan keuntungan dari hasil pemasaran

\section{* Jumlah Konsumen Akhir}

Jumlah konsumen yang diamatai berdasarkan hasil survei yang dilakukan, bahwa jumlah konsumen akhir adalah lebih dari 50 orang, penulis juga menentukan responden konsumen akhir dan diperoleh hasil 50 orang minimal untuk lembaga pemasaran, dengan adanya angka 50 tersebut artinya telur ayam ras banyak diminati oleh masyarakat sebagai sumber protein hewani yang memiliki nilai gizi yang tinggi, dan berapun harga dari telur ayam ras, maka akan tetap dibeli oleh konsumen akhir sebagai kebutuhan sehari-hari, seingga dengan jumlah tersebut srukur pasar untuk jumlah pedagang dan konsumen dikategorikan efisien.

\section{* Kemudahan Telur Ayam Ras Masuk Pasar}

Hasil survei yang dilakukan menunjukkan bahwa telur masuk di pasar tidak terkonsetrasi di wilayah kecamatan Kanigoro saja, bahkan menjual ke kecamatan lain seperti kecamatan Garum dan Talun, serta pedagang pengepul dan grosir serta pihak minimarket yang berasal dari kecamatan Rejotangan kabupaten Tulungagung, selain itu pengiriman telur juga dilakukan oleh lembaga ke kota lain seperti Kediri, kecamatn Sumberpucung kabupaten Malang dan wilayah Trenggalek dan Ponorogo, sehingga jaringan pasar luas dan keuntungan semakin tinggi, keadaan demikian yang menjadikan penilaian untuk struktur pasar dikategorikan efisien.

\section{Perilaku Pasar}

\section{* Praktek Tidak Jujur}

Hasil analisis menunjukka bahwa pemasaran telur ayam ras tidak terdapat parktek yang tidak jujur, semua lembaga bersaing secara sehat untuk menyalurkan barangnya hingga ke konsumen akhir. Sistem pembelian yang dilakukan oleh pedagang pengepul dan minimarket ke produsen adalah dengan cara mengisi kontrak kerja terlebih dahulu karena produsen menginginkan langganan yang tetap, sehingga sebelum pedagang dan pihak minimarket membeli biaya pembelian telur harus diserahkan sebelum telur ayam ras diambil ke produsen, sehingga tidak ada praktek kecurangan yang terjadi antara produsen dengan pedagang

\section{* Pembentukan harga}

Hasil survei dilakukan bahwa harga dibentuk berdasarkan kondisi saat itu, dengan melihat rincian dari biaya yang dikeluarkan pada salah satu itemnya apakah mengalami kenaikan atau tidak, biasanya harga telur naik karena harga DOC atau harga pakan naik, sehingga harga menjadi fluktuaif dan peternak mengalami kesulitan menentukan harga, dalam kesulitan tersebut biasanya ada kebijakan pemerintah yang membantu menentukan harga pasar, serta melihat kondisi lembaga pesaing yang menentukan harga, sehingga informasi pasar penting dalam penentuan harga telur ayam ras.

\section{* Kolusi}

Hasil survei yang dilakukan menunjukkan bahwa tidak ada kolusi antar pedagang, masingmasing pedagang bersaing secara sehat, bahkan apabila salah satu pedagang yang kekurangan stok dari produsen, maka pedagang lain yang memasok telur agar permintaan telur ayam ras berapapun mampu tercukupi, karena masing-masing lembaga memiliki pelanggan yang tetap sehingga pemasaran dikategorikan efisien.

\section{Penampilan Pasar}

\section{* Nilai Margin}

Hasil olah data yang dilakukan diperoleh ratarata nilai margin dari tiga tipe saluran pemasaran memiliki nilai lebih dari harga jual produsen yaitu Rp 14.300,-/kilogram dan distribusi margin tidak merata, karena masing-masing lembaga pemasaran mengambil keuntungan yang berbeda-beda sesuai dengan kegiatan pemasaran yang dilakukan dan sesuai dengan jumlah telur yang dibeli, sehingga dengan adanya nilai margin yang lebih tinggi dari harga jual produsen dan sistem distribusi margin tidak merata maka pemasaran dikategorikan masih efisien [21].

\section{* Ketersediaan Produk}

Hasil survei menunjukkan bahwa produk masih bersifat kontinyu karena hasil pegamatan yang diperoleh 30 peternak yang telah dijumpai di lokasi penelitian sehingga jumlah tersebut adalah menjadi jumlah responden penelitian dengan rata-rata kepemilikan populasi ayam petelur sebanyak 9.183 ekor ayam petelur, sehingga produk tersedia secara kontinyu, dan apabila salah satu peternak tidak bisa memasok permintaan pedagang akan telur ayam ras, maka produsen lain dengan produksi yang melimpah 
yang akan memenuhi kebutuhan telur ayam ras sehingga ketersediaan telur tidak terbatas, hasil tersebut menunjukkan saluran pemasaran yang terjadi masih efisien.

\section{* Share Peternak}

Hasil olah data yang dilakukan berdasarkan saluran pemasaran yang terbentuk diketahui bahwa semua tipe saluran pemasaran satu, dua bahkan tiga (A) dan (B) memiliki share produsen diatas $80 \%$, artinya pemasaran dikatakan efsien, karena semakin mendekati nilai $100 \%$ pemasaran dikatakan efisien, sehingga nilai share produsen tergolong tinggi dan peternak memiliki keuntungan dalam pembagian hasil penjualan telur ayam ras dari beberapa lembaga yang iku serta memasarkan telur ayam ras hingga ke konsumen akhir.

\section{Pengaruh Lingkungan Eksternal dan Internal dalam Pemasaran terhadap Efisiensi Pemasaran}

Gambar 1 merupakan hasil penjabaran bahwa melalui hasil analisa data menggunakan SEM program smartPLS 2.00 diketahui nilai koefisien parameter yang menunjukkan besarnya pengaruh variabel konstruk terhadap efisiensi pemasaran sebesar 95,3\%. Variabel yang berpengaruh terhadap efisiensi pemasaran adalah Budaya, Gaya Hidup, Harga pasar, Jumlah pelanggan, Kelompok sosial, Pengalaman dan Persepsi

\begin{tabular}{ll} 
Tabel 6. Pengaruh Lingkungan Terhadap Efisiensi Pemasaran \\
\hline Indikator & Keterangan \\
\hline Budaya & Signifikan \\
Gaya hidup & Signifikan \\
Harga pasar & Signifikan \\
Jumlah pelanggan & Signifikan \\
Jumlah produksi & Tidak Signifikan \\
Kelompok sosial & Signifikan \\
Motivasi & Tidak Signifikan \\
Pengalaman & Signifikan \\
Persepsi & Signifikan
\end{tabular}

(Data Primer (diolah) 2014)

Tabel 7. Nilai Koefisien Determinasi

Variabel Nilai R-Square $\left(R^{2}\right)$

Efisiensi Pemasaran 0.953

(Data Primer, (diolah) 2015)

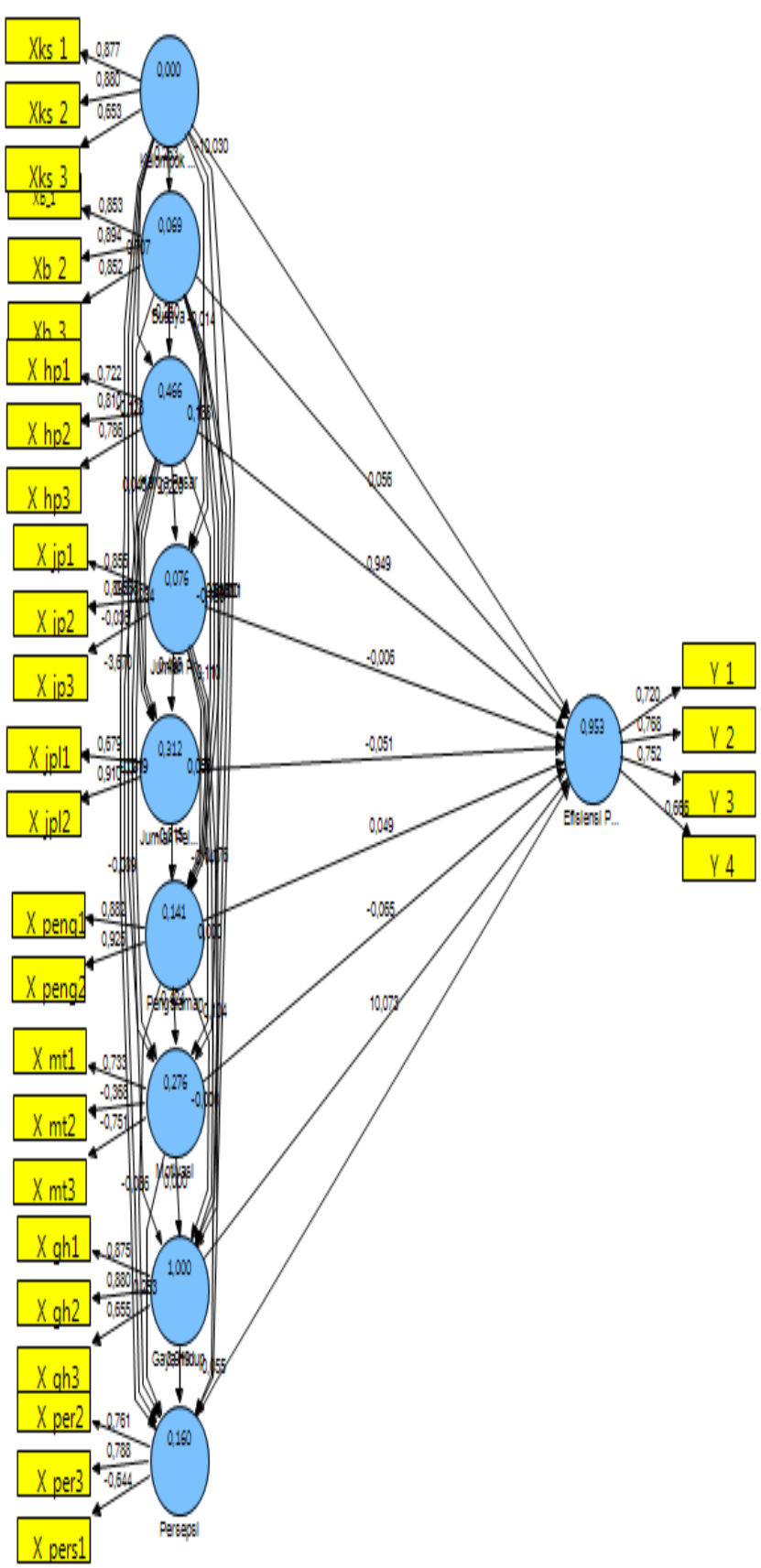

Gambar 1.Intrepretasi Jalur

Nilai koefisien Determinasi untuk variabel Efisiensi pemasaran sebesar 0.953 , bahwa dari makna nilai koefisien determinasi tersebut mengindikasikan bahwa variasi efisiensi pemasaran dapat dijelaskan oleh variabel konstruk (budaya, gaya hidup, harga pasar, jumlah pelanggan, kelompok sosial, pengalaman dan persepsi) sebesar 95,3 \% sedangkan sisanya yaitu sebesar $4,7 \%$ dipengaruhi oleh variabel lain yang tidak terdapat dalam variabel penelitian yang diamati. nilai dari koefisiensi parameter bahwa : Efisiensi Pemasaran $=0,056$ Budaya $+10,073$ Gaya Hidup + 0,949 Harga pasar - 0,051 Jumlah pelanggan + 
10,030 Kelompok sosial + 0,049 Pengalaman $+0,055$ Persepsi.

\section{Pengaruh Budaya terhadap Efisiensi Pemasaran}

Adanya budaya mengkonsumsi telur berarti konsumen semakin sadar akan kandungan gizi telur ayam ras maka akan mengkonsumsi telur ayam ras, yang tadinya tidak mengkonsumsi maka akan tertarik untuk mengkonsumsi, sehingga permintaan akan menjadi banyak, banyaknya permintaan akan membuat banyaknya pedagang yang ikut serta menjalankan kegiatan pemasaran untuk mencari keuntungan, sehingga kelompok sosial berpengaruh signifikan terhadap efisiensi pemasaran yaitu $\mathrm{t}$ hitung $>$ t tabel dengan nilai statistik 10,19>2.

\section{Pengaruh Gaya Hidup terhadap Efisiensi Pemasaran}

Gaya hidup memiliki pengaruh signifikan terhadap efisiensi pemasaran, karena adanya gaya hidup masih berhubungan erat dengan lingkungan sosial dimana yang berasal dari lingkungan yang baik dan sadar akan kandungan gizi telur ayam ras maka akan mengkonsumsi telur ayam ras, yang tadinya tidak mengkonsumsi maka akan tertarik untuk mengkonsumsi, sehingga permintaan akan menjadi banyak, banyaknya permintaan akan membuat banyaknya pedagang yang ikut serta menjalankan kegiatan pemasaran untuk mencari keuntungan, sehingga kelompok sosial berpengaruh signifikan terhadap efisiensi pemasaran yaitu $t$ hitung $>t$ tabel dengan nilai statistik 4,32>2.

\section{Pengaruh Harga Pasar terhadap Efisiensi Pemasaran}

Konsumen akan membeli telur ayam ras dalam jumlah banyak ketika harga di pasar menurun, konsumen berasumsi bahwa harga telur ayam ras di pasar lebih terjangkau dari pada harga telur ayam kampung, telur puyuh dan telur itik, kemudian konsumen juga berasumsi bahwa harga telur ayam ras dijadikan parameter konsumen untuk mensubtitusikan telur ayam ras dengan telur ayam yang lain, akan tetapi dari ketiga sub variabel tersebut yang mewakili variabel pasar yang berpengaruh terhadap efisiensi pemasaran adalah harga telur ayam ras yang menurut responden penelitian bahwa harga telur ayam ras paling terjangkau diantara harga telur yang lain seperti telur ayam kampung, telur itik dan telur puyuh, artinya harga telur yang terjangkau berpengaruh nyata terhadap efisiensi pemasaran karena $t$ hitung lebih besar dari $t$ tabel, angka $t$ hitung dari inner model harga pasar menunjukkan angka lebih besar daripada t tabel 125,09>2,00.

\section{Pengaruh Jumlah Pelanggan terhadap Efisiensi Pemasaran}

Jumlah pelanggan memiliki pengaruh yang signifikan terhadap efisiensi pemasaran, dimana responden berasumsi bahwa semakin banyak jumlah pelanggan maka akan semakin banyak pula lembaga yang ikut serta dalam kegiatan pemasaran karena dengan pelanggan yang banyak stok telur ayam ras yang dibutuhkan juga akan semakin banyak. Pelanggan yang banyak juga berarti muncul kredibilitas antara konsumen akhir dengan lembaga pemasaran, karena mayoritas responden konsumen akhir adalah dari pasar. Jumlah pelanggan berpengaruh signifikan terhadap efisiensi pemasaran karena $t$ hitung lebih besar dari t tabel yaitu 6,96 > 2,00 . Hubungan antara variabel gaya hidup dengan dengan motivasi dengan nilai $r-0,065$ dan persepsi dengan korelasi sebesar 0,055 yang dapat mempengruhi efisiensi pemasaran telur ayam ras memiliki korelasi atau $r$ sebesar 10,073 artinya peran gaya hidup dengan kaitannya pada motivasi dan persepsi terhadap efisiensi pemasaran memiliki pengaruh sebesar atau hubungan sebesar 10,073.

\section{Pengaruh Kelompok Sosial terhadap Efisiensi Pemasaran}

Kelompok sosial merupakan lingkungan Kelompok sosial merupakan lingkungan eksternal dimana responden banyak melakukan kegiatan dan interaksi dari lingkungn tersebut, kelompok sosial biasanya memberikan pengaruh atau masukan terhadap responden karena lingkungan sosial sering melakukan interaksi baik secara langsung dan tidak langsung sehingga kemungkinan untuk memberikan masukan mengenai sesuatu hal yang dikonsumsi akan terjadi, dan menceritakan pengalaman setelah mengkonsumsi telur ayam ras, bahkan memberikan informasi terkait manaat dan kelemahan dari telur ayam ras. kelompok sosial berpengaruh signifikan terhadap efisiensi pemasaran yaitu $\mathrm{t}$ hitung $>\mathrm{t}$ tabel dengan nilai statistik 4,30>2.

\section{Pengaruh Pengalaman terhadap Efisiensi Pemasaran}

Pengalaman merupakan kegiatan yang pernah dilakukan dan konsumen mengetahui dampak baik dan buruk setelah melakukan penjualan telur ayam ras, sehingga pedagang memiliki pengalaman setelah mengkonsumsi telur ayam ras. Semakin banyaknya pengalaman yang dimiliki oleh pedagang berarti semakin banyak pula konsumen yang membeli dari pedagang tersebut karena kepercayaan dari lama pedagang melakukan kegiatannya sebagai penjual telur ayam ras sehingga dalam hal tersebut akan berdampak pada panjang pendeknya saluran pemasaran, dengan pengalaman banyak yang dimiliki oleh pedagang maka banyak pula konsumen yang ingin menjadi pelanggan sehingga banyaknya permintaan akan membuat banyaknya pedagang yang 
ikut serta menjalankan kegiatan pemasaran untuk mencari keuntungan, sehingga pengalaman berpengaruh signifikan terhadap efisiensi pemasaran yaitu t hitung $>$ t tabel dengan nilai statistik 6,02>2 .

\section{Pengaruh Persepsi terhadap Efisiensi Pemasaran}

Persepsi merupakan anggapan responden mengenai kelebihan dan kekurangan dalam mengkonsumsi telur ayam ras. Persepsi merupakan salah satu dorongan yang timbul dari pribadi konsumen akhir kemudian dibandingkan dengan pendapat orang lain akan manfaat dan kekurangan dari telur ayam ras, akan tetapi persepsi lebih banyak dari informasi yang ada pada pendapat diri sendiri. Persepsi dari konsumen akhir terdiri bahwa responden berasumsi jika kualitas telur ayam ras lebih baik dibandingkan dengan telur ayam kampung, telur itik dan telur puyuh, kemudian telur ayam ras aman untuk dikonsumsi segala usia mulai dari usia muda hingga lansia, kemudian responden berasumsi bahwa mengkonsumsi telur ayam ras karena memiliki daya tarik tersendiri selain harganya terjangkau bahwa membeli telur ayam ras merupakan keharusan yang dilakukan responden sehingga selalu ada dan dibeli oleh konsumen akhir. Persepsi berpengaruh signifikan terhadap efisiensi saluran pemasaran, bahwa persepsi baik yang dimiliki oleh responden pada dasarnya akan meningkatkan permintaan telur ayam sehingga adanya persepsi yang positif mengenai telur ayam ras maka permintaan banyak sehingga banyak lembaga pemasaran yang ikut serta melakukan kegiatan pemasaran memanfaatkan banyaknya permintaan sehingga dapat memperoleh keuntungan yang banyak. Hasil analisis statistik bahwa $\mathrm{t}$ hitung lebih besar daripada $\mathrm{t}$ tabel yaitu 11,14 $>2$.

\section{KESIMPULAN DAN SARAN}

\section{Kesimpulan}

1. Pola saluran pemasaran yang terjadi di kecamatan Kanigoro kabupaten Blitar untuk grade $A A$ dan A memiliki 4 tipe saluran pemasaran yaitu tipe 1 peternak - pedagang pengepul - grosir pedagang kecil - konsumen akhir, kemudian tipe 2 peternak -pedagang pengepul - grosir - konsumen akhir, tipe 3 (a) peternak - pengepul - konsumen akhir, tipe 3 (b) peternak - minimarket - konsumen akhir dan tipe 4 untuk grade B peternak - hotel konsumen akhir.

2. Hasil efisiensi pemasaran dilihat dari perhitungan margin dan share peternak bahwa Nilai mark-up paling tinggi adalah untuk saluran yang menggunakan lembaga pemasaran peternak pedagang pengepul - grosir - pedagang kecil konsumen akhir dan Share peternak tertinggi terdapat pada saluran pemasaran mulai dari peternak - pengepul - konsumen akhir dengan nilai efisiensi sebesar $91,08 \%$,

3. Budaya, gaya hidup, Harga pasar, jumlah pelanggan, kelompok sosial dan persepsi berpengaruh positif terhadap efisiensi pemasaran.

\section{Saran}

1. Saluran pemasaran telur ayam ras yang terjadi di kecamatan Kanigoro kabupaten Blitar secara umum masih ada beberapa yang kurang efisien karena margin antara tipe pemasaran satu dengan yang lainnya tidak merata sehingga ada beberapa lembaga yang terlalu mahal menjual telur ayam ras sehingga tidak efisien pada sudut pandang konsumen terutama perlu ditingkatkan pada item penampilan pasar terutama pada item perataan nilai distribusi margin dan efisiensi biaya yang harus dilakukan oleh tipe saluran pemasaran 3 (b).

2. Disarankan agar peternak telur ayam ras di kecamatan Kanigoro jika ingin meningkatkan keuntungan maka memilih saluran pemasaran tipe 3 (a) yaitu pedagang pengepul sebagai lembaga pemasaran terakhir pada tipe 3 (a), selain itu pemasaran juga efisien pada sudut pandang konsumen karena harga jual konsumen akhir lebih murah dibanding dengan tipe saluran pemasaran yang lainnya.

3. Sebaiknya struktur pasar dan penampilan pasar harus lebih diperhatikan oleh lembaga pemasaran, karena saat ini mulai banyak peternak yang menjual telur berdasarkan grade, sehingga tidak mengalami permasalahan harga yang tidak efisien jika produk tersedia terlebih dahulu atau permintaan yang muncul terlebih dahulu daripada produk.

\section{UCAPAN TERIMA KASIH}

Terimakasih kepada dosen pembimbing prof.Dr.Ir. Zaenal Fanani,MS dan Ir.Hari Dwi Utami, MS.M.Appl.Sc.Ph.D serta pihak Pascasarjana Fakultas Peternakan dan lembaga pemasaran telur ayam ras di kecamatan Kanigoro Blitar.

\section{DAFTAR PUSTAKA}

[1]. Makka, D. 2005. Kebijakan Sub Sektor Peternakan Dalam Mendukung Pengembangan Sistem Integrasi Sawit-Sapi. Lokakarya Pengembangan Sistem Integrasi Kelapa SawitSapi. Direktur Pengembangan Peternakan, Ditjen Bina Produksi Peternakan [Daftar Pustaka dari Jurnal]

[2]. Disnak Jatim. 2011. Populasi Ayam Petelur Blitar. Http://Disnakjatim.com. Diakses 28 Sepetember 2014. [Daftar Pustaka dari Website]

[3]. Subagja, H. 2012. Analisis Pemasaran Ayam Broiler. Di Kabupaten Jember. Tesis S2. Sekolah Pascasarjana. 
Universitas Gadja Mada, Yogyakarta. [Daftar Pustaka dar[20]. Carlton, D.W. dan Perloff,J.M. 2000. Modern Industrial Jurnal] Organization $\left(4^{\text {th }} e d\right)$. Boston: Addison-Wesley [Daftar

[4]. Sukirno, S. 2005. Mikro Ekonomi Teori Pengantar edisi Pustaka dari Prosiding] ketiga. PT.Rajagrafindo Persada: Jakarta. [Daftar Pustaka[21]. Sudiyono, A. 2004. Pemasaran Pertanian. Universitas Buku]

[5]. Rizaldi, D. 2010. Analisis Usaha Pemasaran Ayam Ras Pedaging Di Pasar Baru Bogor Jawa Barat. Skripsi Program Sarjana Ekstensi Manajemen Agribisnis Fakultas Pertanian Institut Pertanian Bogor. [Daftar Pustaka dari Jurnal]

[6]. Sihombing, L. 2011. Tataniaga Hasil Pertanian. USU Press. Medan. [Daftar Pustaka dari Buku]

[7]. Soekartawi. 2001. Analisis Usaha Tani. Jakarta : Universitas Indonesia (UI- Press). [Daftar Pustaka dari Buku]

[8]. Emzir. 2009. Metodologi Penelitian Pendidikan Kuantitatif dan kualitatif. Jakarta : PT Grafindo Raja Persada. [Daftar Pustaka dari Buku]

[9]. Pemkab Blitar. 2002. Data Peternak Ayam Petelur Kabupaten Blitar. http://www.pemkabblitar.com. Diakses 28 September 2014. [Daftar Pustaka dari Website]

[10]. Kartono, K. 1996. Pengantar Metodologi Riset Sosial. Bandung: CV. Mandar Maju. [Daftar Pustaka dari Buku]

[11]. Nugraha. 2006. Analisis Efisiensi Pemasaran Jamur Tiram Segar. Institut Pertanian Bogor. Program Agribisnis Pertanian.

[Daftar Pustaka dari Jurnal]

[12]. Anindita, R. 2003. Dasar-dasar Pemasaran Hasil Pertanian. Jurusan Sosial Ekonomi. Fakultas Pertanian. Universitas Brawijaya. Malang. [Daftar Pustaka dari Jurnal]

[13]. Hanafiah dan Saefudin. 2006. Tataniaga Hasil Perikanan.Jakarta: Universitas Indonesia Press. [Daftar Pustaka dari Buku]

[14]. Khols. R.L dan Uhl, J,N. 2002. Marketing of Agricultural Product. Edisi Kesembilan. (New Jersey: Prentice Hall. [Daftar Pustaka dari Buku]

[15]. Nuraeni. 2006. Efisiensi Pemasaran Ayam Buras Di Desa Kalebarembeng, KecamatanBontonompo,Kabupaten Gowa. STPP Gowa. [Daftar Pustaka dari Jurnal]

[16]. Ghozali,I dan Fuad. 2005. Structural Equation Modeling: Teori, Konsep dan Aplikasi Dengan Program Lisrel 8.0, Semarang: Badan Penerbit UNDIP. [Daftar Pustaka dari Buku]

[17]. Swastha, B, dan Handoko.H. 2007. Manajemen Pemasaran Modern. Yogyakarta. Liberty. [Daftar Pustaka dari Buku]

[18]. Edwards, S. 2006. Market Structure Conduct Performance (SCP) Hypothesis Revisited using Stochastic Frontier Efficiency Analysis. Selected paper presented at the American AgriculturalEconomics Association Annual Meeting. Long Beach, California. July 23-26, 2006. [Daftar Pustaka dari Jurnal]

[19]. Colander, D.C. 2010. Macroeconomics. ( ${ }^{\text {th }}$ ed). McGrawHill.

[Daftar Pustaka dari Prosiding] 